\title{
ALUMINUM ALLOYS
}

UDC 669.715:620.186

\section{EFFECT OF IRON AND MANGANESE CONTENT ON THE STRUCTURE OF CAST ARTICLE FROM ALUMINUM ALLOY AK12}

\section{T. A. Bogdanova, ${ }^{1}$ G. A. Merkulova, ${ }^{2}$ and T. R. Gil'manshina ${ }^{2}$}

Translated from Metallovedenie i Termicheskaya Obrabotka Metallov, No. 9, pp. 3 - 7, September, 2018.

\begin{abstract}
The effect of manganese and iron on the structure of AK12 silumin is studied by microscopic $\mathrm{x}$-ray diffraction and spectrum analyses. Experimental alloys with $\mathrm{Fe}: \mathrm{Mn}=1: 0,1: 0.5,1: 0.7$ and $1: 1$ are investigated. Quantitative analysis of the microstructure is performed. The hub zone is studied for two models of car wheels. Recommendations for alloying AK12 silumin with manganese and iron for raising its mechanical characteristics are given.
\end{abstract}

Key words: silumin, structure, ingot, wheel disks.

\section{INTRODUCTION}

Silumins are widely used industrial alloys, for example, in the automotive industry for making wheel disks. One of the main alloying elements in castable aluminum alloys (silumins) is silicon. A typical silumin is eutectic alloy AK12 (A112) containing $10-13 \% \mathrm{Si}$ (Fig. 1) [1]. The $(\mathrm{Al}+\mathrm{Si})$ eutectic is an acicular one, and therefore the alloy is subjected to refining and modifying. In accordance with GOST 1583-93, a standard aluminum alloy AK12 has the following chemical composition (in \%): $(10-13) \mathrm{Si}, 0.70 \mathrm{Fe}, 0.50 \mathrm{Mn}$, $0.60 \mathrm{Cu}, 0.30 \mathrm{Zn}, 0.10 \mathrm{Mg}, 0.10 \mathrm{Ti}$, the remainder $\mathrm{Al}^{3}$

Specialists of the "KiK" Company and of the Institute of Nonferrous Metals and Materials Science in Krasnoyarsk have performed a series of studies of the structure and properties of silumins cast under low pressure [2-4]. The mechanical properties of disks are standardized by GOST R 50511-93. The presence of iron in the silumin lowers the mechanical properties of disks. In order to save blend materials, the "KiK" Company has tried replacement of primary aluminum of grade A8 with aluminum A7. In accordance with GOST 11069-2011, the A8 aluminum may contain at

1 "KiK" Company, Krasnoyarsk, Russia.

2 Siberian Federal University, Krasnoyarsk, Russia (e-mail: gam1602@mail.ru).

3 Here and below in the paper the content of elements is given in wt.\% if not mentioned specially. most $0.12 \%$ iron impurity, while for the $\mathrm{A} 7$ aluminum the figure is $0.16 \%$. The alloy acquires additional iron due to its presence in silicon. As a result, commercial alloy AK12 contains up to $0.20 \%$.

Iron is frequent and hard-to-remove admixture in aluminum and its alloys. This impurity may affect unfavorably the ductility of fluidity of aluminum alloys [5-7]. The negative action of iron of the mechanical properties of silumins can be neutralized to a certain degree by introducing compensating elements that suppress formation of inclusions of acicular

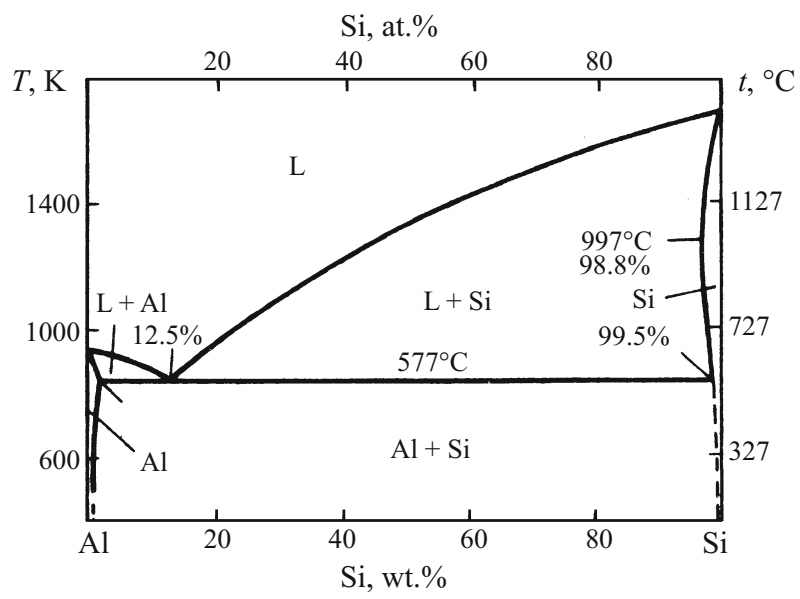

Fig. 1. Phase diagram of the $\mathrm{Al}-\mathrm{Si}$ system [1]. 
TABLE 1. Chemical Compositions of Experimental Aluminum Alloys

\begin{tabular}{cccccc}
\hline \multirow{2}{*}{ Alloy } & \multirow{2}{*}{$\begin{array}{c}\text { Primary } \\
\text { aluminum }\end{array}$} & $\begin{array}{c}\mathrm{Fe}: \mathrm{Mn} \\
\text { proportion }\end{array}$ & \multicolumn{3}{c}{ Content of elements, \% } \\
\cline { 4 - 6 } & & $\mathrm{Si}$ & $\mathrm{Fe}$ & $\mathrm{Mn}$ \\
\hline 1 & $\mathrm{~A} 8, \mathrm{~A} 85$ & $1: 0$ & 11.4 & 0.15 & 0.01 \\
2 & $\mathrm{~A} 7$ & $1: 0.5$ & 11.2 & 0.19 & 0.09 \\
3 & & $1: 1$ & 11.3 & 0.21 & 0.20 \\
4 & & $1: 0.5$ & 11.3 & 0.30 & 0.17 \\
5 & & $1: 0.7$ & 11.3 & 0.25 & 0.17 \\
6 & & $1: 1$ & 11.3 & 0.32 & 0.31 \\
\hline
\end{tabular}

phase $\mathrm{Al}_{5} \mathrm{FeSi}$. Such elements are manganese, which forms an $\mathrm{Al}_{15}(\mathrm{Fe}, \mathrm{Mn})_{3} \mathrm{Si}_{2} \alpha$-phase in the silumins containing iron impurity; this phase weakens the embrittlement. Other compensators are $\mathrm{Cr}, \mathrm{V}, \mathrm{Ni}$, etc.

Iron dissolves well in liquid aluminum and its alloys but has very low solubility in solid aluminum. Therefore, iron bonds to other elements forming intermetallic particles of various types. In the presence of silicon, aluminum alloys acquire the following phases: ternary $\left(\mathrm{Al}_{8} \mathrm{Fe}_{2} \mathrm{Si}\right)$ and quaternary $\left(\mathrm{Al}_{15}(\mathrm{Fe}, \mathrm{Mn})_{2} \mathrm{Si}_{2}\right)$ kinds of $\alpha$-phase of a hieroglyph type and an $\mathrm{Al}_{5} \mathrm{FeSi} \beta$-phase in the form of lamellas. Ironcontaining intermetallics are observable easily in the microstructure of alloys of the $\mathrm{Al}-\mathrm{Si}$ system. In should be noted that the quaternary type of $\alpha$-phase may have a more compact lump-like form or even a form of a polygonal crystal [5-7].

It has been suggested to introduce manganese into silumins as an iron-compensating element in order to provide the required mechanical properties.

We have shown the positive role of manganese in the case of replacement of primary aluminum A8 with $\mathrm{A} 7$ in the production of AK12 in $[2,4]$. This has reduced the cost of automobile wheel disks without lowering their quality. The castable aluminum-based alloy has been patented (No. 2576707) [8].

The aim of the present work was to study the effect of manganese on the microstructure of experimental alloys based on AK12 and containing iron and manganese in various concentrations by optical and electron microscopy.

\section{METHODS OF STUDY}

We fabricated six experimental alloys (Table 1) where the iron content was varied from 0.15 to $0.32 \%$ at iron-tomanganese proportions of $1: 0,1: 0.5,1: 0.7$, and $1: 1$. Alloy 1 was melted from aluminum A8, and alloys $2-6$ were melted from aluminum A7. The blends for the $\mathrm{Al}-\mathrm{Si}$ alloys with up to $0.15 \%$ iron contained primary aluminum A85 (GOST 11069-2001) and crystalline silicon Kr00 (GOST 2169-69). The alloys with $0.19-0.32 \%$ iron were melted from primary aluminum A7 and A7E (GOST 11069-2001), crystalline silicon Kr00 (GOST 2169-69) and AlMn20(B) alloying addition (GOST 53777-2010).

The blends were melted in an IAT-2.5 induction furnace by the standard process at the smelter shop of the "KiK" Company. The chemical compositions of the alloys are presented in Table 1.

The microstructure of the experimental alloys and of the ready articles, i.e., wheel disks cast under low pressure at the "KiK" Company, was studied on microsections using OLIMPUS GX 51 and Axio Observer optical microscopes at a magnification of up to $\times 1000$ and an EVO 50 scanning electron microscope ${ }^{4}$ with an INCA Energy 350 energy dispersive microanalyzer.

The images of the microstructure were analyzed automatically using the AxioVision Carl Zeiss software.

The mean size of dendrite cells ${ }^{5}$ was determined with the help of a Program Wizard computational module and the "Solid Solution" software. The prepared microsections allowed us to study the whole of the surface of a specimen. We chose five most characteristic regions and determined the size of dendrite cells at a magnification of $\times 200$, which allowed us to analyze a large area of a lap with high enough resolution of the structural components of the modified alloy AK12. The obtained values of the size of dendrite cells were processed statistically using the Excel software. The results of the computations gave us the mean size of dendritic cells in the cast structure of alloy AK12; the measured data were processed statistically using the "Descriptive Statistics" and "Histogram" functions of the "Data Analysis" package.

We computed the following parameters of the microstructure of the studied zone of a wheel from alloy AK12: (1) the dendritic parameter of the $\alpha$-solid solution $(d)$, (2) the length of silicon particles in the eutectic $\left(L_{\mathrm{Si}}\right)$, and (3) the volume fraction of silicon in the eutectic $\left(V_{\mathrm{Si}}\right)$.

\section{RESULTS AND DISCUSSION}

To determine the optimum concentrations of iron and manganese in alloys of the $\mathrm{Al}-\mathrm{Si}$ system for low-pressure casing of disks of automobile wheels, we used commercial alloy AK12 produced by the "KiK" Company.

The results of the studies of the microstructure of alloys $1-6$ with different proportions of iron to manganese are presented in Fig. 2.

The structure of alloy AK12 contained an $\mathrm{Al}+\mathrm{Si}$ eutectic. The alloy was modified with AlTi5B1 and AlSr10 alloying additions. All the phases (including the $\beta$-phase) were identified with the use of the data of $[5-7,9-12]$.

The structure of the alloy without additional alloying with manganese was represented by a modified eutectic and

\footnotetext{
4 The studies were performed in 2016 by S. V. Ponomareva (Department of Metal Science and Heat Treatment of Siberian Federal University).

5 The computations were performed with consultation of T. N. Drozdova (Siberian Federal University).
} 

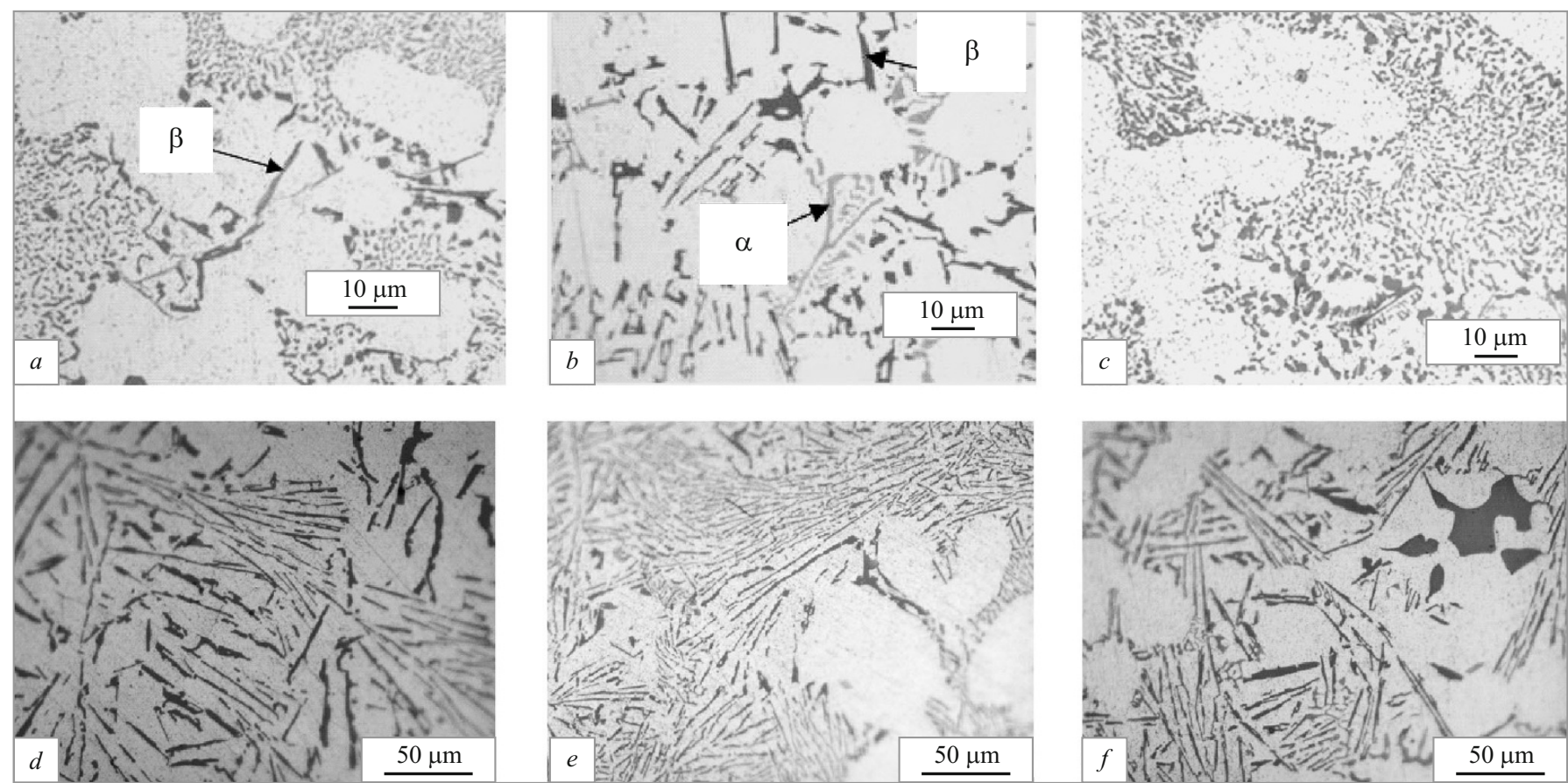

Fig. 2. Microstructure of aluminum alloys $1(a), 2(b), 3(c), 4(d), 5(e)$, and $6(f) . \times 500$.

coarse needles of $\beta$-phase with stoichiometric composition $\mathrm{Al}_{5} \mathrm{FeSi}[9-12]$ (Fig. 2a).

At $\mathrm{Fe}: \mathrm{Mn}=1: 0.5$, the structure contained microvolumes with coarse inclusions of $\beta$-phase and an $\alpha$-phase, i.e., an $\mathrm{Al}_{15}(\mathrm{Fe}, \mathrm{Mn})_{3} \mathrm{Si}_{2}$ intermetallic [9-12] in the form of a Chinese hieroglyphs (Fig. $2 b$ ).

When the content of manganese in alloy AK12 was raised to $\mathrm{Fe}: \mathrm{Mn}=1: 1$, the acicular modification of the iron phase disappeared and a more compact $\alpha$-phase appeared over the whole of the cross section of the lap (Fig. 2c). Formation of a structure known as "Chinese hieroglyphs" [9-12] indicates that the introduction of an appropriate content of the compensating element suppresses formation of a needle-like $\beta$-phase.

The structure of alloys $4-6$ with an elevated iron content and different $\mathrm{Fe}: \mathrm{Mn}$ proportions is presented in Fig. $2 d-f$. It can be seen that it is represented by an $\alpha$-solid solution and an acicular $(\alpha+\mathrm{Si})$ eutectic. The sizes of the needles in alloys 4 and 6 are larger than in alloy 5. This may be explained by the higher contents of iron in alloys 4 and 6 as compared to alloy 5 ( $>0.3$ and $0.25 \%$, respectively). Alloy 5 has a finer structure than alloys 4 and 6 . It can be interred from Fig. 2 that the AK12 grade should not contain more than $0.3 \% \mathrm{Fe}$.

We studied the structure of specimens cut from two models of car wheels under an electron microscope (Figs. 3 -5). The disks of different models differ in the thickness, which affects their structure and properties. This means that the level of the mechanical properties and the structure of the metal in the zones of the rim, spoke, and hub require regular control.

The zone of the hub presented much interest because it had the coarsest structure. The specimens studied had Fe $: \mathrm{Mn}=1.0,1: 0.5,1: 1$ (alloys $1-3$ ).

Figure 3 presents the microstructure of the hub from a disk of model $I$, which contains $0.15 \% \mathrm{Fe}$ and virtually no

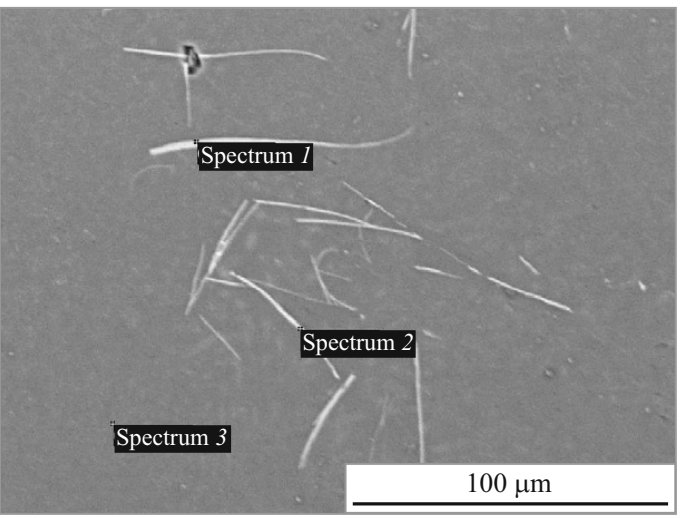

\begin{tabular}{cccc}
\hline \multirow{3}{*}{ Spectrum } & \multicolumn{3}{c}{ Content of elements, wt.\% } \\
\cline { 2 - 4 } & $\mathrm{Al}$ & $\mathrm{Si}$ & $\mathrm{Fe}$ \\
\hline 1 & 67.76 & 18.07 & 14.16 \\
2 & 72.17 & 13.36 & 14.47 \\
3 & 67.17 & 32.83 & - \\
\hline
\end{tabular}

Fig. 3. Structure of the hub from a disk of model $I$ with $\mathrm{Fe}: \mathrm{Mn}=1: 0$ and results of its spectrum analysis. 


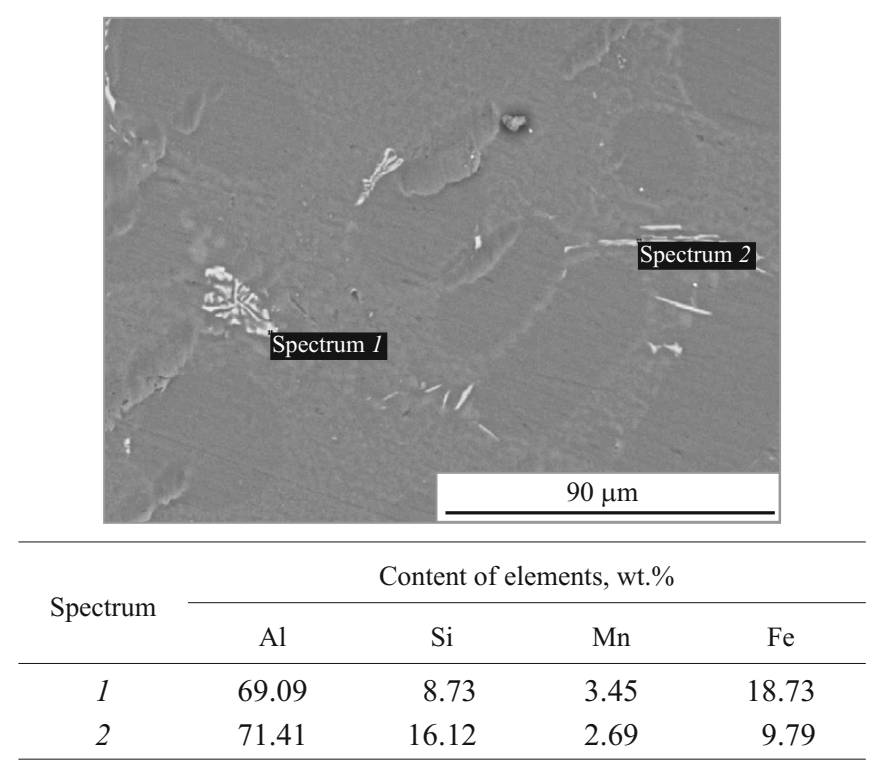

Fig. 4. Structure of the hub from a wheel of model $I$ with $\mathrm{Fe}: \mathrm{Mn}=1: 0.5$ and results of its spectrum analysis.

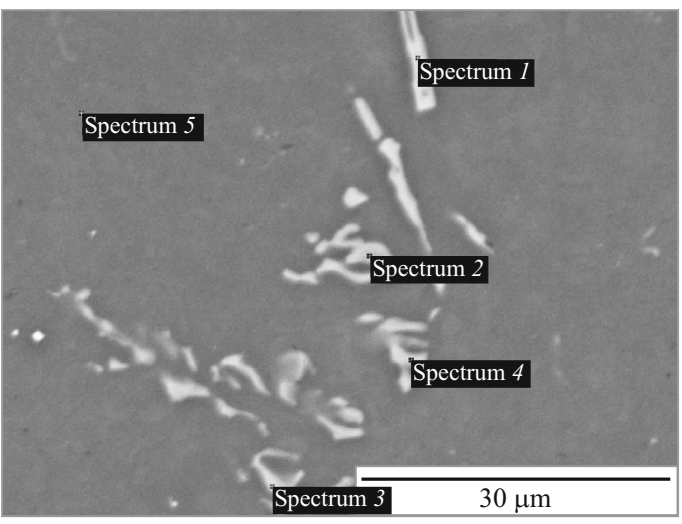

\begin{tabular}{ccrcr}
\hline \multirow{2}{*}{ Spectrum } & \multicolumn{4}{c}{ Content of elements, wt.\% } \\
\cline { 2 - 5 } & $\mathrm{Al}$ & \multicolumn{1}{c}{$\mathrm{Si}$} & $\mathrm{Mn}$ & \multicolumn{1}{c}{$\mathrm{Fe}$} \\
\hline 1 & 56.43 & 23.45 & 7.77 & 12.35 \\
2 & 81.54 & 6.96 & 4.83 & 6.66 \\
3 & 76.56 & 8.68 & 6.38 & 8.37 \\
4 & 77.71 & 7.90 & 5.62 & 8.77 \\
5 & 89.45 & 10.55 & - & - \\
\hline
\end{tabular}

Fig. 5. Structure of the hub from a wheel of model $I I$ with $\mathrm{Fe}: \mathrm{Mn}=1: 1$ and results of its spectrum analysis.

Mn (about $0.01 \%$ ), i.e., $\mathrm{Fe}: \mathrm{Mn}=1: 0$. The particles of an acicular $\beta$-phase $\mathrm{Al}_{5} \mathrm{FeSi}$ containing (spectrum 2 ) $72.17 \% \mathrm{Al}$, $13.36 \% \mathrm{Si}$ and $14.47 \% \mathrm{Fe}$ are well observable.

The structure of the alloy with $\mathrm{Fe}: \mathrm{Mn}=1: 0.5$ is presented in Fig. 4. We can see acicular particles of $\alpha$-phase accompanied by compact particles of $\mathrm{Al}_{15}(\mathrm{Fe}, \mathrm{Mn})_{2} \mathrm{Si}_{2}$ shaped as hieroglyphs $[4,10-11]$ (spectrum 1 in Fig. 4) and containing $69.09 \% \mathrm{Al}, 8,73 \% \mathrm{Si}, 18.73 \% \mathrm{Fe}$ and $3.45 \% \mathrm{Mn}$.
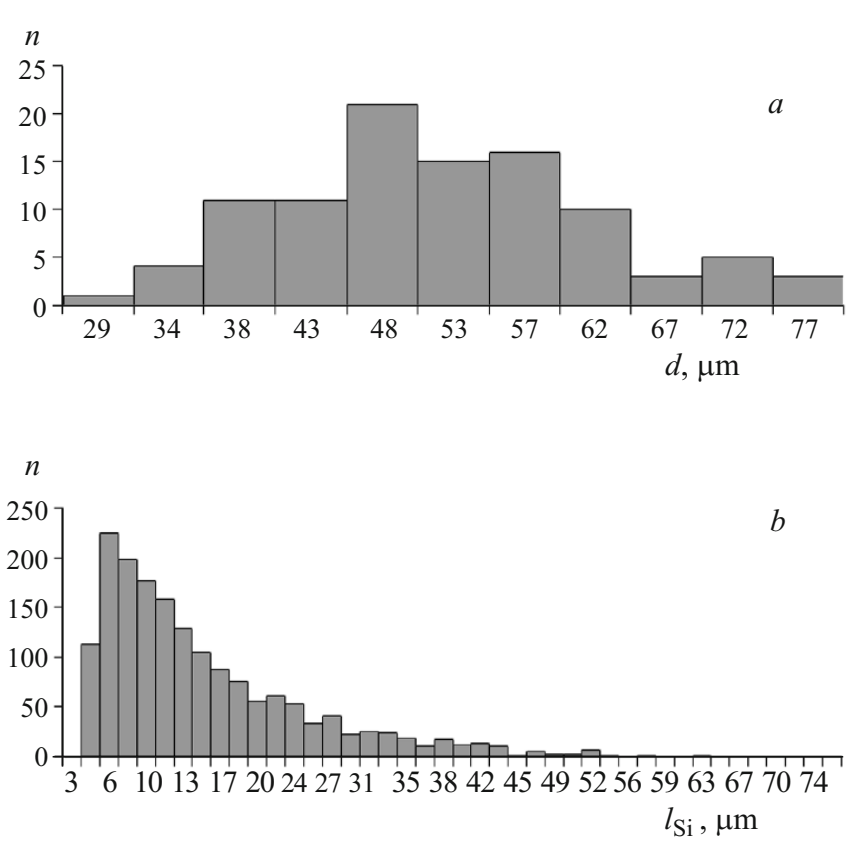

Fig. 6. Histogram of the size distribution of dendrite cells of the $\alpha$-solid solution ( $a$ ) and of the distribution of silicon particles with respect to the length $(b)$ for alloy 6 ( $n$ is the number of cases).

Figure 5 presents the structure of a disk of model $I I$ with $\mathrm{Fe}: \mathrm{Mn}=1: 1$. It contains a compact quaternary phase $\mathrm{Al}_{15}(\mathrm{Fe}, \mathrm{Mn})_{2} \mathrm{Si}_{2}$ bearing $77.71 \% \mathrm{Al}, 7.90 \% \mathrm{Si}, 8,77 \% \mathrm{Fe}$, and $5.62 \%$ Mn (spectrum 4 in Fig. 5). Thus, the study of the structure of the test specimens shows that the proportion of iron to manganese in alloy AK12 should be amended to $1: 1$, which promotes formation of a compact iron-containing phase.

A quantitative analysis of the structure was conducted with the aim to determine the effect of the rates of crystallization of the alloy in different zones of a wheel on the structure, in particular, in the spoke zone. We studied alloy 6 with $\mathrm{Fe}: \mathrm{Mn}=1: 1$. The size of a dendrite cell and the size of the particles of silicon in the eutectic determine the mechanical properties of the disks of car wheels. The results of the study are presented in Fig. 6 and Table 2.

The histogram of the size distribution of dendrite cells of the $\alpha$-solid solution (Fig. $6 a$ ) is bilaterally symmetrical. This reflects stability of the sizes and shows visually that the hits occur chiefly in the middle region of the histogram and their number decreases to the edges. By the data of the earlier studies [2], the mechanical properties of the alloy are optimum at $\mathrm{Fe}: \mathrm{Mn}=1: 1$ (like in alloy 6 ). The required level of the ultimate strength, of the elongation and of the conventional yield strength are obtained when the size of a dendrite cell in the $\alpha$-solid solution ranges within $49.46 \pm 4.46 \mu \mathrm{m}$ (Table 2). This is provided by high rates of crystallization of the alloy in all zones of the wheel.

The histogram of the length distribution of silicon particles in the eutectic (Fig. $6 b$ ) is asymmetrical and shows that the majority of the values are shifted to the left. This reflects 
TABLE 2. Parameters of the Microstructure of Alloy AK12 in the Zone of a Disk Spoke (Alloy 6 )

\begin{tabular}{lccc}
\hline Structure component & $\bar{d}, \mu \mathrm{m}$ & $L_{\mathrm{Si}}, \mu \mathrm{m}$ & $V_{\mathrm{Si}}, \%$ \\
\hline $\begin{array}{l}\text { Primary dendrite } \\
\text { of } \alpha \text {-solid solution }\end{array}$ & $49.46 \pm 4.46$ & - & - \\
$\alpha+$ Si eutectic & - & $14.7 \pm 1$ & $15.9 \pm 0.9$ \\
\hline
\end{tabular}

Notations: $\bar{d}$ ) mean size of dendrite cells; $L_{\mathrm{Si}}$ ) length of a particle of $\mathrm{Si}_{\text {eut }} ; V_{\mathrm{Si}}$ ) volume fraction of $\mathrm{Si}$ in the eutectic.

the great number of small silicon needles in the eutectic, the degree of modification of the alloy, and the high crystallization rate. The volume fraction of silicon in the eutectic is $15.9 \pm 0.9 \%$ (Table 2 ).

\section{CONCLUSIONS}

1. The structure of alloy AK12 with $\mathrm{Fe}: \mathrm{Mn}=1: 0$ $(0.15 \% \mathrm{Fe})$ contains particles of an acicular $\alpha$-phase $\mathrm{Al}_{5} \mathrm{FeSi}$. In the case of $\mathrm{Fe}: \mathrm{Mn}=1: 0.5(0.19 \% \mathrm{Fe})$, the $\alpha$-phase is accompanied by compact particles of $\mathrm{Al}_{15}(\mathrm{Fe}, \mathrm{Mn})_{3} \mathrm{Si}_{2}$ of a hieroglyphic shape. The proportion of $\mathrm{Fe}: \mathrm{Mn}=1: 1$ $(0.21 \% \mathrm{Fe})$ provides formation of a dominantly compact quaternary phase $\mathrm{Al}_{15}(\mathrm{Fe}, \mathrm{Mn})_{3} \mathrm{Si}_{2}$.

2. Introduction of manganese into the studied silumin requires a content of Fe no more than $0.25 \%$, to avoid coarsening of the structure; in this case the proportion of $\mathrm{Fe}: \mathrm{Mn}=$ $1: 1$ does not improve the structure.

3. By the data of the quantitative analysis of the microstructure of alloy 6 with $\mathrm{Mn}: \mathrm{Fe}=1: 1$, the mechanical properties standardized by GOST R 50511-93 are obtained when the size of the dendrite cells of the $\alpha$-solid solution ranges within $49.46 \pm 4.46 \mu \mathrm{m}$ and the length of the silicon particles is $14.7 \pm 1 \mu \mathrm{m}$.

\section{REFERENCES}

1. L. F. Mondolfo, Structure and Properties of Aluminum Alloys [Russian translation], Metallurgiya, Moscow (1979), 640 p.

2. T. A. Bogdanova, N. N. Dovzhenko, T. R. Gil'manshina, et al., Structure Formation in Castable Aluminum Alloys under Low-Pressure Casting [in Russian], SFU, Krasnoyarsk (2015), $164 \mathrm{p}$.

3. T. A. Bogdanova, Development of Competitive Process for Casting Car Wheels from a Silumin Based on A7 aluminum, Author's Abstract of Candidate's Thesis [in Russian], Krasnoyarsk (2015), $23 \mathrm{p}$.

4. T. A. Bogdanova, N. N. Dovzhenko, T. R. Gil'manshina, et al., "Effect of Fe/Mn proportion on the structure and properties of alloy AK12," Liteinoe Proizvod., No. 9, 5 - 8 (2015).

5. R. S. Rana, Rajesh Purohit, and S. Das, "Reviews on the influences of alloying elements on the micro-structure and mechanical properties of aluminum alloys and aluminum alloy composites," Int. J. Sci. Res. Publ., 2(6), 1 - 7 (2012).

6. Salem Seifeddine, "The influence of iron on the microstructure and mechanical properties of cast $\mathrm{Al}-\mathrm{Si}$ alloys. Rap. 24," Ingenjörshögskolan i Jönköping, Dec. 20, 20 (2007).

7. J. A. Taylor, "The effect of iron in $\mathrm{Al}-\mathrm{Si}$ casting alloys," in: 35th Australian Foundry Inst. National Conf., 31 Oct - 3 Nov. 2004, AFI, Australia, pp. 148 - 157.

8. T. A. Bogdanova, S. I. Kuklin, E. I. Kuklin, et al., "Aluminumbased castable alloy, Patent 2576707 RF, MPK C22C 21/02, Appl. No. 2014123014/02, 05.06.2014," Byull. Izobr. Polezn. Modeli, No. 7 (2016), publ. 10.03.2016.

9. A. G. Prigunova, N. A. Belov, Yu. N. Taran, et al., Silumins. An Atlas of Microstructures and Fractograms of Commercial Alloys [in Russian], MISiS, Moscow (1996), $175 \mathrm{p}$.

10. I. I. Novikov, G. B. Stroganov, and A. I. Novikov, Metal Science, Heat Treatment and X-Ray Investigation [in Russian], MISiS, Moscow (1994), $480 \mathrm{p}$.

11. V. S. Zolotorevskii and N. A. Belov, The Physical Metallurgy of Castable Aluminum Alloys [in Russian], MISiS, Moscow (2005), 375 p.

12. V. D. Belov and N. A. Belov, "About some aspects of production of shaped castings from "secondary" silumins in Russia," Metalloved. Term. Obrab. Met., No. 9, 33 - 39 (2011). 